Article

\title{
Economic Productivity vs. Ecological Protection in Danube Floodplain. Case Study: Danube's Sector between Olt and Vedea
}

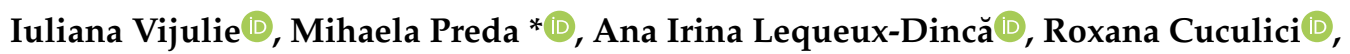 \\ Elena Matei ${ }^{\mathbb{D}}$, Alina Mareci $\mathbb{D}^{\mathbb{D}}$, Gabriela Manea ${ }^{\mathbb{D}}$ and Anca Tudoricu $\mathbb{D}$ \\ Faculty of Geography, Bucharest University, N. Bălcescu, 1, 010041 Bucharest, Romania; \\ iuliana.vijulie@g.unibuc.ro (I.V.); ana.dinca@geo.unibuc.ro (A.I.L.-D.); roxanacuculici@yahoo.com (R.C.); \\ elena.matei@g.unibuc.ro (E.M.); alina.mareci@unibuc.ro (A.M.); maneagabriela2002@yahoo.com (G.M.); \\ anca.tudoricu@gmail.com (A.T.) \\ * Correspondence: mihaela.preda@geo.unibuc.ro; Tel.: +40-2131-503-74
}

Received: 11 October 2019; Accepted: 12 November 2019; Published: 14 November 2019

\begin{abstract}
For a long time, wetlands were perceived as non-productive areas and were drained in an attempt to increase Romania's agricultural surface, without acknowledging their ecological functions. This paper aims to identify possible ecological restoration models for the Danube floodplain according to the principles of sustainable development and the needs of the population living and working here. The research methodology included direct field observation, GIS techniques, and the survey method. The analysis proved the need for achieving the ecological restoration of this area while ensuring a harmonious relationship between nature and economic activities. After evaluating the views of local decision-making actors, different groups of stakeholders with divergent opinions emerged. While owners of agricultural holdings and agriculture experts pleaded for maintaining the status quo, NGOs voted for complete ecological restoration, and landowners with small farms, local authorities' representatives, and environmental experts argued for partial ecological restoration. The study emphasises that the ecological restoration of the Danube floodplain is necessary but only possible through a consensus between the existing stakeholders and done based on the principles of sustainable development (conserving its biodiversity, protection against floods, economic activities).
\end{abstract}

Keywords: wetlands; ecological restoration; agriculture; ecology; sustainable development; Danube floodplain; Romania

\section{Introduction}

Humanity has, along history, neglected the protective benefits offered by natural areas in favour of economic development, but during the last 100 years, numerous research and measurements proved that climate has undergone considerable changes, changes that lead to extreme meteorological phenomena increasing in frequencies especially during the last few decades [1]. The correlation between the two is a subject to countless studies and panels, and the result is the present trend to reverse stakeholders' opinion and supporting the development of projects that acknowledge natural areas' fundamental ecological functions (climate regulators, source of clean water and air, protection against extreme phenomena) [2].

Wetlands' conversion into arable lands was meant to generate economic development through the practice of an intensive agriculture, but their most important ecological functions are nowadays being rediscovered. They represent habitats for numerous endangered or vulnerable species as well as hydrologic polders, and areas that could mitigate floods, with the latter role becoming ever more critical in the present context of climate change. 
Ecological restoration is, in this context, an essential sensitive topic which interests many government policies in their attempt to plan development while mitigating ecosystem damage [3]. Considered a key element of biological conservation, the concept is very much analysed nowadays through its human dimensions as the collaboration between land managers and stakeholders or the ecological economics, and adequate policies are considered sometimes more important than the technical or biophysical knowledge [4] in assuring the success of ecological restoration projects and planning.

The Danube floodplain was embanked and drained in order to increase the country's agriculture areas, construct ports or industrial plants, develop access networks, or exploit their natural resources (e.g., wood, reed). This affected $95 \%$ of the upper Danube, $75 \%$ of its lower basin, and $25 \%$ of the Danube Delta's flooded areas [5]. These changes took place primarily between 1960 and 1980, and they coincided with a policy of nationalizing most of the private properties. After the year 1990 most of the areas in the Danube floodplain are still being used for agriculture, but their property status has changed. Most of them are still state property but were leased to agricultural holdings. The rest are privately owned either by landowners with small farms or by the above-mentioned agricultural holdings. As the study will present, the area's agricultural role is less profitable in some cases. Moreover, the damages and loses caused by floods in Romania have recently considerably increased [6]. This situation was fuelled partly by human interventions in the wetlands but also by climate change which has had damaging consequences during the last few years $[7,8]$. The tangible results of such destructive events required an increase in the public's awareness regarding the need for the ecological restoration of the wetlands that had previously been drained. Nowadays the population directly impacted by these damages seems visibly more interested in maintaining and restoring the ecosystem functions as well as in the open-air leisure opportunities provided by wetlands [9-11]. Consequently, the reconversion of agricultural areas in naturally flooded ones is a challenging process, but if done correctly, it can generate economic benefits as well as improve the ecosystem [12-14].

Climate change became an important variable to be considered when planning along the Danube area. As such, even as far back as the year 2000 Romania, Bulgaria, Serbia, the Republic of Moldova, and Ukraine signed The Lower Danube Green Corridor Declaration as part of the Living Danube Partnership initiated by the World Wide Fund (WWF) and agreed on by the EU [15]. The four states commit themselves to restore 900.000 ha of presently cultivated areas to a wetlands state, 223.608 ha of which are to be reintroduced to their natural aquatic environment by Romania alone, in an attempt to conserve and sustainably manage and rebuild some of the most biodiverse regions in the world. In order to support this ecological programme, the Danube Delta National Institute for Research and Development conducted between 2006 and 2008 a study on the ecological restoration in the Danube Delta and Danube floodplain entitled The Ecological and Economic Resizing Programme in Romanian Sector of the Danube floodplain [16]. This is one of the most important documents on this topic as it maps the areas in the Danube floodplain that are eligible for ecological restoration, and, as such, it was used by the authors when constructing the two proposed restoration models.

The first ecological restoration projects of the Romanian sector of the Danube floodplain were initiated by the World Wildlife Fund (WWF) in partnership with the Ministry of Environment, a series of research centres (e.g., the Danube Delta National Institute for Research and Development, Tulcea), and NGOs. Projects like the works done in Gârla Mare (Mehedinți County), Goștinu-Greaca-Chirnogi (Giurgiu and Călărași Counties), and Balta Geraiului (Olt County) located west of the study area are an example of ecological restoration implemented by WWF next to older projects from the Danube Delta that were developed inside the abandoned agricultural areas Babina and Cernovca, in cooperation with research institutes and NGOs. A series of scenarios for transforming current agricultural lands within the Danube floodplain into areas for water storing and rebalancing of the natural conditions were proposed during the "Ecological and Economic Resizing Programme in Romanian Sector of the Danube floodplain" [16,17]. 
The paper "The ecological restoration of the flooded area of the Romanian Danube" published in 2008 further emphasised the idea of a national re-evaluation of all the existing infrastructure in this area from an ecological, social, and economic perspective, while also analysing measures to preserve its biodiversity [18]. Additionally, worth taking into consideration is the fact that inside the study area several Natura 2000 sites exist (e.g., ROSCI: Corabia-Turnu Măgurele, Gura Vedei-Saica-Slobozia; ROSPA: Olt-Danube confluence, Suhaia Lake, Vedea-Danube confluence. These are areas of remarkable biodiversity and significant to future restoration efforts. The most important of these protected areas is Suhaia Lake [19], entitled Natura 2000 area (ROSPA0102 Suhaia-avifauna special protection site) through the Governmental Decision no. 1284/2004 [20]. It contains parts of a meadow and flooding area which feeds from the Danube through the Gârla Iancului channel and contains pastures and swamps with wetland-specific flora and fauna which host and ensure favourable conditions for feeding and nesting to numerous species of migratory birds. In 2012 Suhaia Lake was declared a RAMSAR Site- - a wetland of international importance, and waterfowl habitat. The area contains ponds as well as swamps, channels, and reeds, a sector of the Danube made out of beams, backwaters, and silted branches, etc. [21]. Internationally, Suhaia Lake is presently recognised as a major component of Danube's floodplain, while also being part of the restoration plan of the Lower Danube Green Corridor. The launch of the Danube European Strategy extended the area of interest for scientific works to include the river's ecological functions and public land use. Further on the Danube Floodrisk Project, coordinated by the Ministry of Environment (2009-2012), aiming to create a base for ensuring the sustainable development of all activities along the Danube River by building efficient hazard maps for the Danube floodplain was elaborated and presented valuable information about flood hazards, essential for conducting successful spatial and economic planning policies [22-24]. Other works that analysed the possibility of achieving ecological restoration in former wetlands from the lower Danube are authored by Hein and Funk $[25,26]$. The last official documents that refer to the ecological restoration of the Danube floodplain are the Strategy for the Sustainable Development of Romania 2030 [27], in accordance with the 2000/60/CE Water Directive Framework [28] and the 2007/60/CE Directive on Floods [29] (which govern bodies of water in the European Union), and also the European strategies for managing the effects of global warming $[25,26,30]$.

All scientific literature identifies a major problem that, while having multiple facets, touches the entire Danube floodplain and stems from two sources: The region's history and the current reality brought over by climate change and can be summarized as a decrease in the overall profitability of the land. In fact, it is represented by aridisation and soil erosion which happened gradually and was caused by the embankments done in the floodplain [5,31,32]. The periodical flooding, that occurred before embankment, ensured that the soil would replenish its nutrients and controlled its salinity level. The direct consequence of the draining and the embankment works is a lower agricultural yield and hence lower economic profits, but it also generated another unexpected problem: The dry soil, combined with a lack of supporting vegetation, was unable to mitigate the effects of the now stronger and more frequent floods, and as such caused significant material damages to the population living in the Danube floodplain.

Consequently, it is necessary to construct models for the ecological restoration of the Danube floodplain that are based on the perception, needs, and interests of the local stakeholders and maintain a balance between the natural landscape and the current and possible future economic activities the area can sustain. The authors emphasised the importance of contacting and interviewing local stakeholders and including their perception, and thus support, in the study as one of the major conflicts in the process of implementing any policy that refers to ecological restoration will be the divided and antagonistic position of the local population. Their position stems from a natural sense of place [33]. In this particular situation, their conservative attitude is generated by the change in paradigm regarding their own ownership status over the land, brought forward by experiencing two types of government and both a system of centralised economy and a free market economy, each with their pros and cons.

As such, the objectives of the study unfolded according to the following phases: 
O1-Identifying possible models for the future restoration of the Danube floodplain;

O2-Evaluating the perception of stakeholders involved in the current and future use of the plots from the Danube floodplain, as a key factor for translating the principles of sustainable development into a future ecologic restoration of the area.

\section{Study Area}

The area of interest, respectively the sector between the Olt and Vedea river outlets on the Danube, is located in the southern part of Teleorman County (Romania). Its northern limit is the Danube upper terrace and the Boian Field, where several human settlements are located. The Danube floodplain sector between Olt's outlet in the West and Vedea's outlet in the east was chosen by our study because it is part of the Lower Danube flooded area and respectively the part of the Danube floodplain where human impact was most severely felt (see Figure 1).

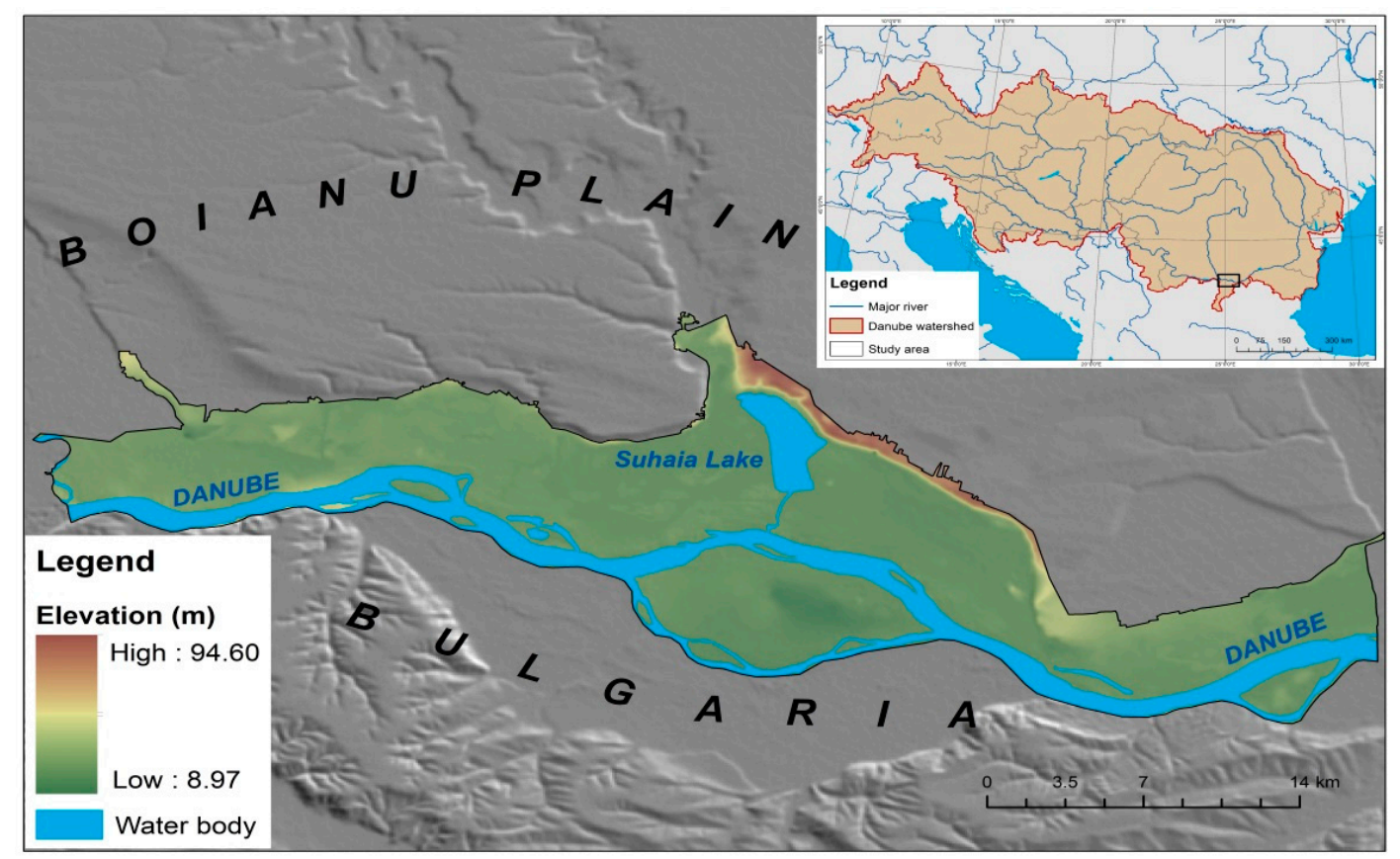

Figure 1. Location of the study area within Europe and the Danube Basin.

\section{Materials and Methods}

The authors proposed the workflow chart below (see Figure 2) in order to identify the possible models of ecological restoration of the studied segment, while also taking into account the opinions of the stakeholders involved in the current and future use of this area.

The main research methods employed during this study included field observation, GIS techniques, and a key-type study in the form of an exploratory or pilot study using, as a research instrument, semi-structured interviews [34-36]. Most of the previous studies [37-40] focused on hydrological and hydraulic modelling, taking into account one-dimensional (1D) simulations such as ISIS [41] or multiscale two-dimensional simulations such as CLASSIC — climate and land-use scenario simulation in catchments [42], DIVAST—depth-integrated velocities and solute transport, or JFLOW [43]. In creating the current situation for the land-use map, the authors used the 2018 Corine Land Cover database downloaded from the European Environment Agency's website [44], which was subsequently validated using information from $100 \mathrm{~m}$ resolution Landsat satellite images from Google Earth Pro application (these images were used on 1 July 2019) [45].

At a national level, the study "The Ecological and Economic Resizing Programme in Romanian Sector of the Danube floodplain" by the Danube Delta National Institute for Research and 
Development [16] is the one that analyses the area in the most detail but still only quantifies the Danube floodplain into areas that are eligible for ecological restoration and areas that are not. There are no detailed propositions for how exactly any ecological restoration would take place in the sector between Olt and Vedea, which is what the authors of this study set up to do. When presenting an ecological restoration plan the authors were first confronted with the task of deciding to what degree this restoration will enfold. As such it was decided to create two possible restoration scenarios, named "models", with the first one presenting a more progressive view and a second one considered to be a compromise between the existing situation and the basic needs for restoration.

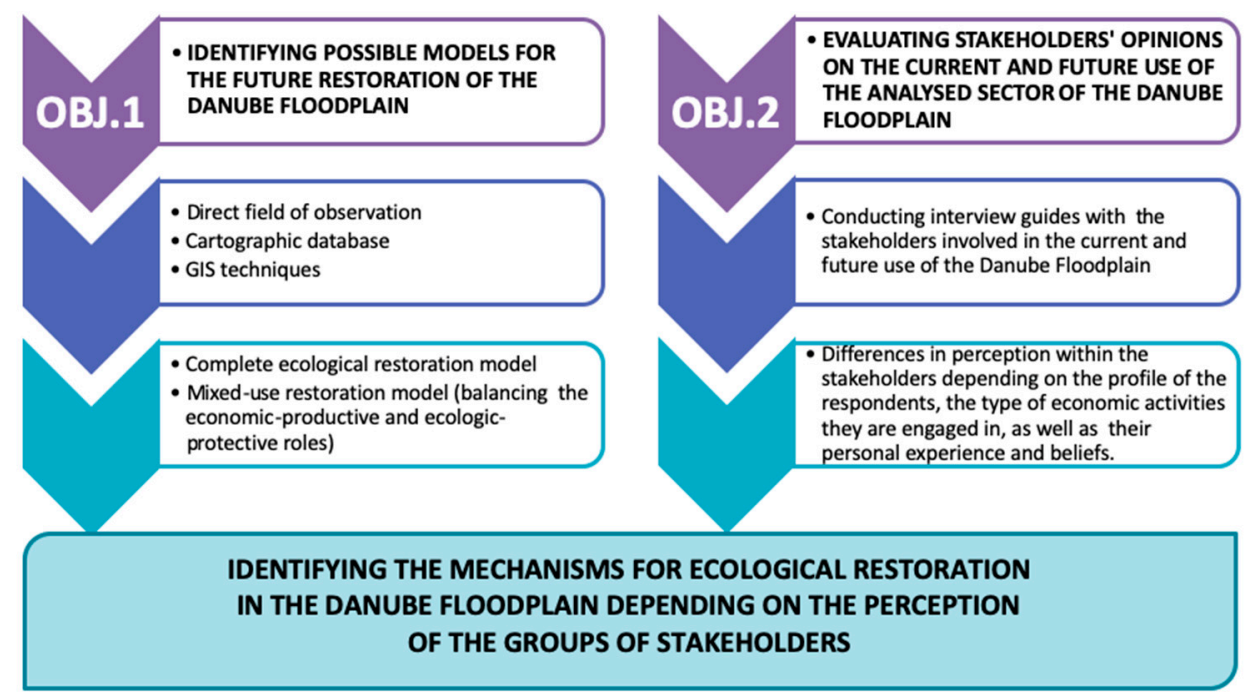

Figure 2. Research workflow chart.

The 1912 Austria Map (1:200,000) [46] was observed in order to construct the first ecological restoration model, because this is the best image of the study area before the processes of drainage and embankment started. The authors built up this first model using GIS techniques and intended it to reflect a land-use typology as close as the initial state of the Danube floodplain, while also considering the history of human changes it went through along the years. The second ecological restoration model was constructed starting with the current (2018) land-use typology, and exemplifies a vision of the principles of sustainable development that balances the study area's economic-productive and ecologic-protective roles. GIS techniques were also used for this stage.

The second objective required field observations, which were done by the authors from April to July 2019, and intended, on one side, to complete and validate the data obtained through GIS techniques and, on the other, to conduct 83 interviews with the stakeholders involved in the current and future use of the Danube floodplain inside the study area. The main key stakeholder groups interested and/or affected by the ecological restoration of the area and approached by our study were farmers (landowners of small farms and owners or representatives of agricultural holdings), local authorities, experts, and NGOs representatives. Their opinion regarding the land use of the Danube floodplain remains a crucial factor in obtaining the "strategic optimum" [47], from a sustainability perspective, for the local community and economy. The semi-structured interview also contained open questions, allowing discussions and free expression of ideas, and it was considered the most convenient tool to the different types of respondents in order to empower interviewers to better grasp different opinions on the current and especially future situation regarding the land use management of the study area, similar to other studies.

The population directly impacted by any changes done in the study areas, namely the two types of farmers were sampled, and the process was a stratified one. The interviews were held according to the age of the respondents (young adults, $18-35$ years old $-16.87 \%$; old adults, $36-60$ years old $-49.40 \%$; 
and elderly population, above 60 years old-33.73\%). The weight of each age group reflects the demographic structure of the population living in the study area [48]. The interviewed farmers formed two distinctive groups. The first group included landowners of small farms (with plots that are in general smaller than $3 \mathrm{ha}$ ). The highest degree obtained by $82.5 \%$ of them was the high-school level, while the rest of the respondents only got a primary level education. More than half of them (55\%) were elderly, 35\% old adults and the rest being young adults. This target group contained mostly males (30), to only 10 females, because traditionally men are the ones present at fairs organised during weekends in villages around Romania. The second group of interviewed farmers were in actuality owners or representatives of agricultural holdings which manage land plots they bought, or that are state-owned but were farmed out, or sometimes plots leased from locals (landowners of small parcels from the study area). They were agronomist engineers, managers, or accountants of agricultural holdings, and these categories were chosen as they are deciding factors in their own field of work, while also having the technical expertise to obtain improved yields per hectare. All of them were graduates of superior educational institutions with $60 \%$ being old adults, and the rest breaking evenly between young adults and elderly population. A total of 40 landowners with small farms and 10 owners or representatives of agricultural holdings were interviewed. The 4:1 rapport was established because even if the landowners with small farms cover a considerably less extensive surface of the study area, their number is significantly superior, as such, despite their importance in land ownership, this corresponds to their numeric distribution and is a good tool to approach the social dimension as a key principle of sustainable development in the area on the other.

Part of the authors attended weekly fairs in Ciuperceni (Poiana village), Seaca, Suhaia and Năsturelu, in order to meet with the small farms' landowners, while others went to the towns of Turnu Măgurele and Zimnicea in order to meet the owners or representatives of large agricultural holdings.

The major questions that were addressed to both groups of interviewed stakeholders included whether or not they were using the entire land area that they owned/managed, whether or not they were satisfied with the agricultural production obtained, whether or not they considered investments in hydro-improvement works as a good opportunity for them, and whether or not they are happy to maintain the status quo. All the discussions ended with the presentation of the two proposed ecological restoration models and discussions with the interviewees on how much they would support each of them and also what are in their opinion the direct effects that any restoration project would have on them. During the discussions with the landowners with small farms, the authors were confronted with the lack of information this group had regarding the concept of ecological restoration and what exactly it means for their everyday reality. This is supported by the fact that most of the landowners with small farms have a limited education and knowledge about specialised views on ecology in general. As such, the first question facing the authors was "what is ecological restoration, be it partial or complete" and "what good will it do to us". The authors had to explain the concept of restoration and what the potential benefits would be, but also the necessary steps to achieve it which would request a series of sacrifices on the part of the general population. As such the authors distributed flyers to the locals gathered at the weekend fairs with information on the environmental issues that the local communities face in the context of climate change (e.g., frequent floods and droughts, aridisation), as well as information about how ecological restoration works could mitigate the situation (e.g., improving the local microclimate, restoring biodiversity, preventing floods and droughts). At the same time the topic of economic growth was approached, as the authors tried to inform the local population that even though the immediate effect of ecologic restoration was losing significant areas of arable land, the opportunities generated by the territorial modelling concept of economic productivity through ecological protection (e.g., developing fish farms, creating systems of forest shelterbelts, selective wood processing, possibly developing leisure and ecotourism activities) would improve, in the long term, the quality of life for the population living in the Danube floodplain. This step was necessary to validate the choice of the landowners with small farms between a future partial or complete ecological 
restoration of the analysed floodplain sector. This discussion aimed to measure the degree to which the interviewees would accept or agree with such an initiative.

The representatives of the local public authorities represented another stakeholder group that was approached by this study also in their capacity of political and administrative decision agents. They consisted of members of local councils and city hall officials from localities in which the landowners with small farms lived. The authors also investigated the expert opinion of specialists in the field of the current and future use of the territory of the Danube floodplain in order to supplement the local experience; method other studies have also used [49]. All the experts had a superior education level. The experts pertained to a variety of fields such as agricultural and forestry specialists, land-use improvement, biology, hydrology, environment protection and conservation, territorial planning, etc. They made a series of arguments for or against a partial or complete ecological restoration, according to their field of study (agriculture, forestry, environment, tourism). The NGOs representatives made out the last group of stakeholders interviewed, with all of them having graduated from a superior educational institution.

Both the specialists and the NGOs representatives were selected regardless of their age and location, but based on their expertise. Their age reflected most of the times their position and education level. Discussions included questions on the validity of keeping the status quo, the need for ecological restoration, and the feasibility of each of the two proposed models [50].

All these groups were asked about their agreement of maintaining the status quo, to what degree they would support any of the ecological restoration models presented, and what were, in their opinion, the main obstacles in achieving ecological restoration in the study area.

\section{Results}

\subsection{Identifying Possible Models for the Future Restoration of the Danube Floodplain}

The result of the research, corroborated with previous researches [16,51,52], proves the existence inside the study area of regions eligible for future restoration works. Two possible models for a sustainable Danube floodplain restoration were generated. In elaborating the two possible models the authors considered the current land-use typology as well as all the human interventions that shaped the Danube floodplain. The first proposed model used the Austrian map as a reference of the initial state of the Danube floodplain (see Figure 3).

After 1950, Romania has seen a period of a forced planned economy. This translated into consequential agricultural measures meant to increase productivity using mechanisation and overall modernisation of all economic sectors. The implementation of an intensive type of agriculture required the maximisation of all available land plots including turning most of the wetlands from the Danube floodplain into agricultural areas. This has shaped the current land-use typology (see Figure 4).

Several research papers approached the issue of ecological restoration and creation of water-storing areas in the Danube floodplain, known as "room for the river and nature" following the model of Dutch-managed "Making space for rivers" projects [33,51,52].

The first model imagines ecological restoration done inside the areas drained during the 20th century through hydro-technical works (see Figure 5a). The main reason why the 1912 land-use image cannot be fully achieved through any ecological restoration project is that after 1960 the area experienced several agricultural improvement works (embankment works, draining of the lakes, and levelling of the terrain). This was all done in order to include, in the total agricultural surface of the country, the lands inside the floodplain, as these were highly fertile due to the nutrients washed here by the alluviums of the Danube. The former wetlands became arable plots, pastures, vineyards, or orchards. The only human settlement that existed before this point in time is still present in the place spot and is the present-day Poiana village, called Flămânda before. After the embankment and draining works began several other built-up areas emerged: The port developments in Târgu Măgurele, silos, industrial farms, transport infrastructure, irrigation systems, etc. When building 
the first model, the authors' maintained intact Poiana village, the existing transport infrastructure, and Turnu Măgurele's port and focused on restructuring the rest of the area. The project would involve creating breaches in the protection dikes and flooding the meadows, so they become flooding areas with swamps and ponds, as closely as possible to their reference state from the 1900s. The dikes would be provided with sluices to regulate the Danube in years of strong floods. The main advantage of this model, besides the reduction in flood risks, is that the flooding areas would gradually recover, the soil would desalinate, and the fish population would increase considerably, thus recreating the wetlands. The newly formed ponds and swamps would increase the humidity in the area which under the current climate change is susceptible to aridisation.

"In the years of high floods.... The entire Danube floodplain becomes a sea in the true sense of the word with powerful waves ... a fish farm develops on its flooded meadows". [53] (p. 2)

In the same model, the economic activities could be reconfigured, as the members of the local communities would engage in environmentally friendly activities: fishing, grazing, wood and reed processing, ecotourism, etc. Actions for ecological restoration together with the existing natural protection areas would be a long-term solution for the study area when considering the possibility of extending the natural habitats as breeding areas for several fish and bird species. The first restoration model would support the writings of Grigore Antipa according to which the Danube floodplain is primarily a reservoir of storing high floods [53].

The second restoration model involves a mixed-use of the analysed sector, respectively activities that would combine sustainable economic growth with ecological exploitation of the region. This would be possible by consolidating the existing dikes and building new ones that would protect the arable lands drained before 1990, thus creating new pocket-chambers for the river that would control the water level and allow the rebuilding of wetlands (see Figure 5b). The 2006 floods proved that if such Dutch-like chambers existed on the river, the downstream water level would generally decrease and, in case of flooding, localities situated downstream could be saved through controlled flooding. Rooms for the river are original and distinctive elements for land use planning in Romania [51]. They could have a double function: Protection against flooding and also irrigation for vegetable gardens that could be set up around them and which, in turn, could become a source of fresh vegetables for the inhabitants of nearby urban areas. Presently just increasing the height of existing dikes can no longer be a viable long-term solution, because climate change is expected to exacerbate even more flood risks as well as flood levels. Other proposals included in the second model of restoring the Danube floodplain envisage firstly creating fish ponds on Suhaia Lake and restoring the former rice paddies around it, and secondly creating forest shelterbelts that would protect agricultural lands from aridisation and soil erosion, a crucially important aspect in view of current climate change trends (see Figure 5b).

"If the natural and economic conditions allowed for it, some parts would be valued through agriculture, some through fishing, others would be left as meadows or would be forested, and others will become built-up/industrial areas, etc.". [53] (p.7)

The re-establishment of rice paddies in the area is a viable ecological idea, as this type of crops ensures a moderation of the local, aridity-prone climate, by maintaining areas flooded several months per year during the summer season [54]. The biodiversity issue is also taken into account by this model, as it will support the increase in hygrophilous and hydrophilic species and even the bird species that will use the wetlands and the hygrophilous vegetation for nesting or feeding, as proved by the results from establishing the Suhaia Lake RAMSAR Site.

Overall, the second model for restoration recommends a mixed-use of the study area, namely creating a balance between its economic-productive and its ecologic-protective roles.

Each of the two models come with their own advantages and disadvantages, which are the starting points of the discussions with the stakeholders when deciding to what degree they would support each of them (see Figure 6). 


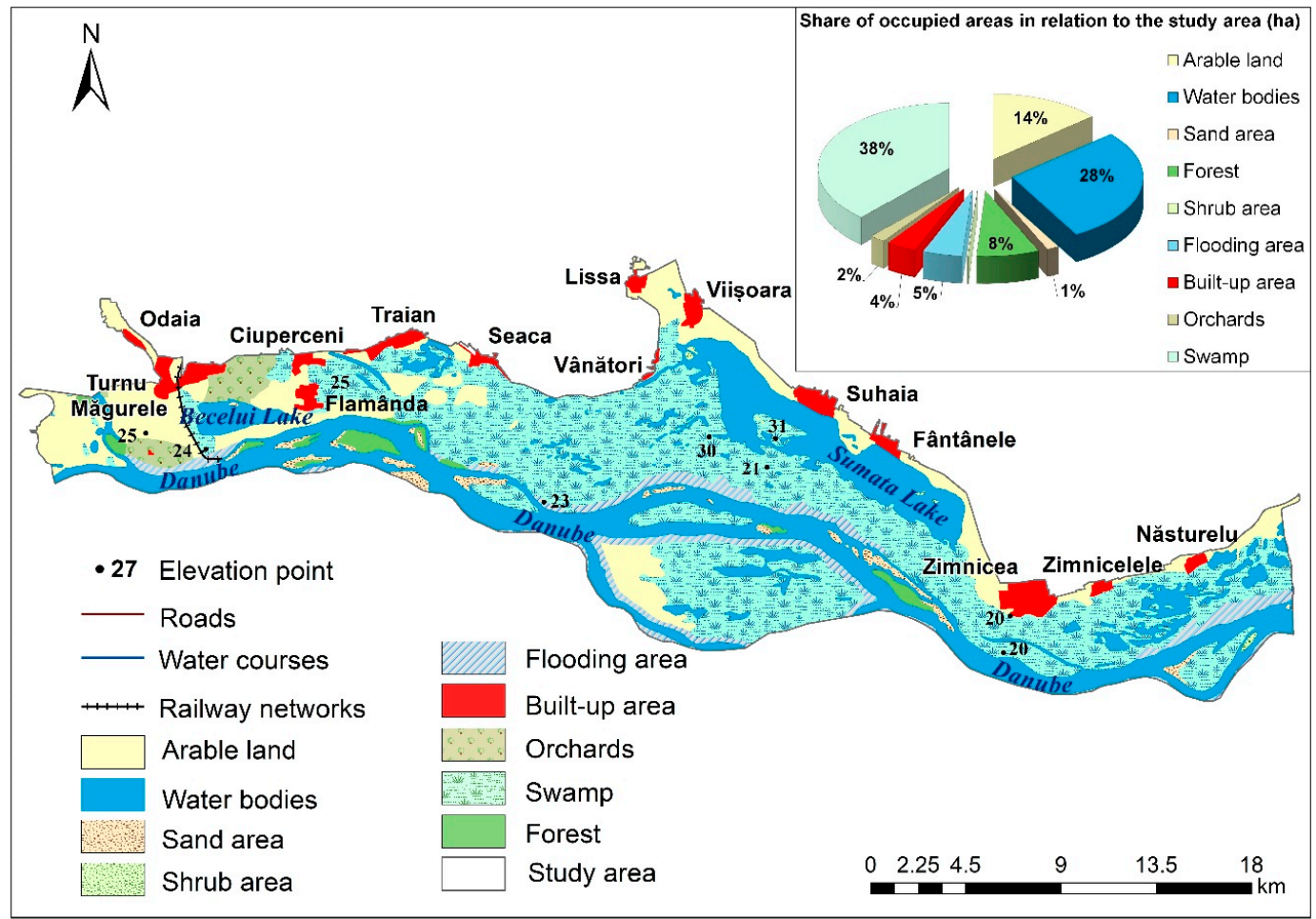

Figure 3. Land use in the Danube floodplain in 1912 (sector between Olt and Vedea). Source: The 1912 Austrian Map at a 1:200,000 scale.

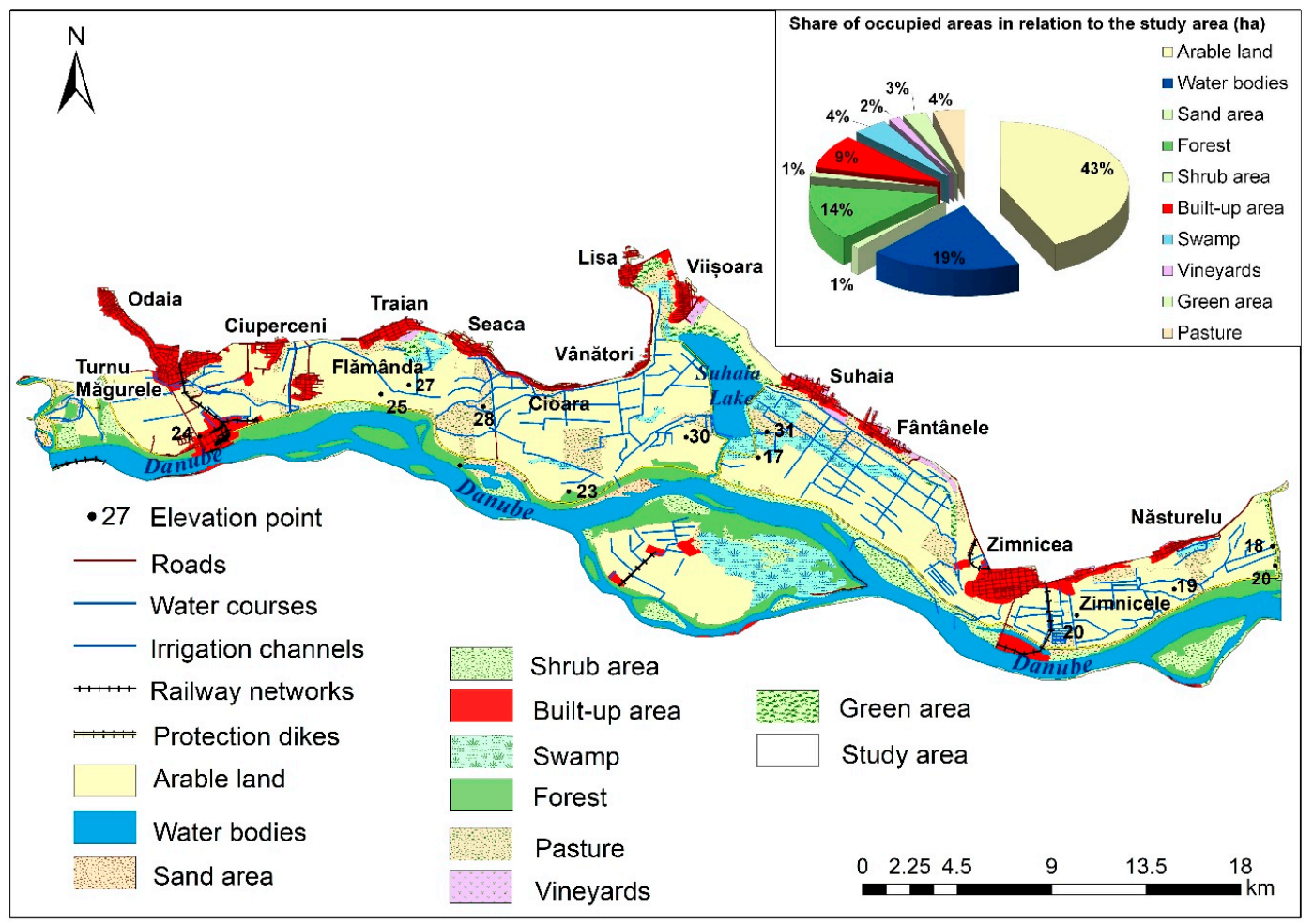

Figure 4. Current land use structure in the Danube floodplain (sector between Olt and Vedea). Source: 2018 Corine Land Cover database. 


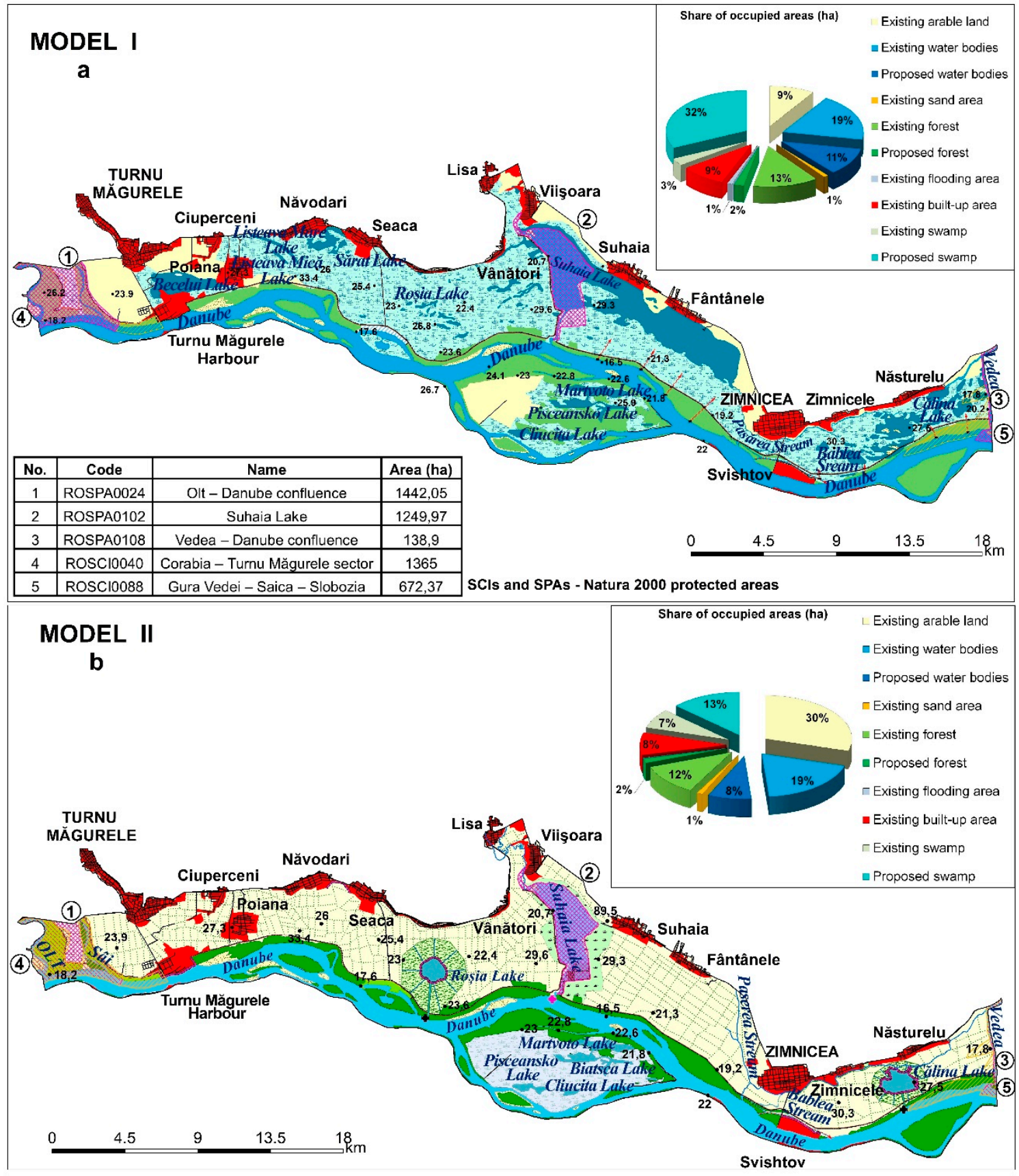

\section{A. Existing types of land use and infrastructure}

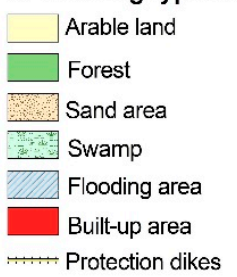

- Irrigation channels

- Roads

Water courses

-27 Elevation point

- Water pumping station

SPA (Special Protection Area)

$\mathrm{SCl}$ (Site of Community Importance)
B. Proposed ecological restoration (land use and infrastructure

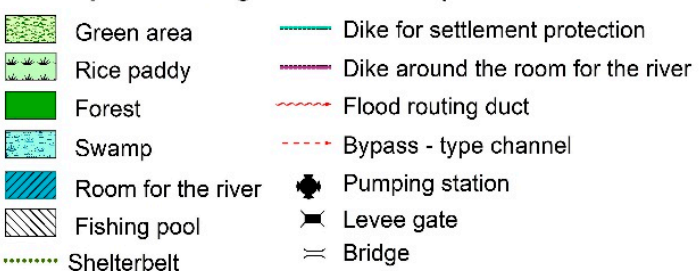

Figure 5. (a) Model I (complete ecological restoration); (b) Model II-mixed-use (sustainable economic-ecological exploitation). Source: adaptation from the Danube Delta National Institute for Research and Development, 2008 [16]. 


\begin{tabular}{|c|c|c|}
\hline & PROS & CONS \\
\hline $\begin{array}{c}\text { Model I } \\
\text { Total } \\
\text { ecological } \\
\text { restoration }\end{array}$ & $\begin{array}{l}\text { - Controlling the flooding of the floodplain } \\
\text { and recreating wetlands } \\
\text { - Reintegrating the former lakes and ponds } \\
\text { in the natural hydrological circuit } \\
\text { - Expanding natural habitats, increasing } \\
\text { biodiversity (hygrophilous and } \\
\text { hydrophilic fauna and flora) } \\
\text { - Ensures the successful mitigation of the } \\
\text { effects brought forward by climate } \\
\text { change, which will only enhance (floods, } \\
\text { droughts, aridisation of the soil) } \\
\text { - Supports practising traditional, } \\
\text { environmentally friendly economic } \\
\text { activities (fishing, hunting, grazing, reed } \\
\text { and rush processing, ecotourism) }\end{array}$ & $\begin{array}{l}\text { - Losing areas that are presently used for } \\
\text { agriculture or grazing, or that contain } \\
\text { industrial constructions, transport } \\
\text { infrastructure, or agricultural } \\
\text { improvements such as irrigation equipment } \\
\text { - There is no legislation in place that ensures } \\
\text { the financial compensation of the owners } \\
\text { whose private lands will be flooded } \\
\text { - The new lakes and ponds will not entirely } \\
\text { fill their former basin because the draining } \\
\text { and embanking works changed the } \\
\text { topography of the terrain } \\
\text { - Restoring a hydrological and ecological } \\
\text { balance to the area will take time } \\
\text { - Eliminating from use of agricultural lands } \\
\text { will generate social conflicts due to the } \\
\text { conservative attitude of the local } \\
\text { population regarding their ownership of } \\
\text { the land brought forward by experiencing } \\
\text { both a system of centralised economy and a } \\
\text { free market economy }\end{array}$ \\
\hline $\begin{array}{l}\text { Mode1 II } \\
\text { Partial } \\
\text { ecologic } \\
\text { restoration }\end{array}$ & $\begin{array}{l}\text { - A mixed use of the land represents a } \\
\text { compromise between two extreme } \\
\text { positions (a fully agricultural use or full } \\
\text { transformation into wetlands) } \\
\text { - Flooding will be done only in areas that } \\
\text { are best suited for it (those areas currently } \\
\text { neighbouring lakes or ponds) } \\
\text { - Ensures the mitigation of the effects } \\
\text { brought forward by climate change, } \\
\text { which will only enhance (floods, } \\
\text { droughts, aridisation of the soil) } \\
\text { - The pocket-chambers will ensure the } \\
\text { better protection against severe floods on } \\
\text { the Danube River by more successfully } \\
\text { regulating it while also ensuring an } \\
\text { irrigation reserve } \\
\text { - Offers the possibility to continue } \\
\text { practising agriculture and animal } \\
\text { husbandry } \\
\text { - Offers the possibility to rethink some of } \\
\text { the economic activities inside the } \\
\text { embanked areas (paddy fields, fish } \\
\text { ponds) } \\
\text { - A more diversified economy will be more } \\
\text { stable } \\
\text { Will increase the local biodiversity } \\
\text { (spontaneous fauna and flora) }\end{array}$ & $\begin{array}{l}\text { - A reduction of the agricultural activities } \\
\text { will directly reflect the profits obtained } \\
\text { from this particular activity and eliminating } \\
\text { from use of some agricultural lands could } \\
\text { general social conflicts } \\
\text { - Flooding will affect lands that are presently } \\
\text { used for agriculture or grazing, or that } \\
\text { contain industrial construction, transport } \\
\text { infrastructure, or agricultural } \\
\text { improvements such as irrigation equipment } \\
\text { - The economic costs of implementing this } \\
\text { project are higher because some areas } \\
\text { proposed for flooding are not presently } \\
\text { totally occupied by lakes and ponds (Roşia } \\
\text { și Călina) }\end{array}$ \\
\hline
\end{tabular}

Figure 6. The advantages and disadvantages of the two proposed models.

\subsection{Evaluating Stakeholders' Opinions on the Current and Future Use of the Analysed Sector of the Danube Floodplain}

This objective aims to analyse stakeholders' opinions on the current and possible future land use of the Danube floodplain and the study identified significant differences of opinion between the decision-making actors who lastly determine the land use transformation inside the study area. Each of the expressed positions reflects the respective group's interests and principles related either to production activities or conservational views. In this context, obtaining a "strategic optimum" between 
the groups of stakeholders who are the ecological or economic beneficiaries of the development potential of the Danube floodplain proved extremely challenging.

The landowners of small farms mostly practice a subsistence type of agriculture meant to sustain only their household. Eighty percent of them voiced their disapproval about the current manner in which the land in the analysed sector of the floodplain is used. Many of them rented out their plots to agricultural holdings but are not satisfied with the monetary profit or quantity of produce they receive in return. Some of them mentioned that they had abandoned the arable lands they own because they cannot cover the production costs. They also pointed out that investments in hydro-ameliorative works are very costly, and that their current income does not even cover their daily needs, let alone paying for water necessary for irrigation. Still, $92.5 \%$ of them do not support the idea of complete ecological restoration measurements. This scepticism is rooted in the fear of losing their lands again, as they experienced before 1990 when the country had a planned economy. This sentiment is still fresh in their memory as they have barely regained their properties through the implementation of the Law 18/1991 for the Land Fund [55] (see Figure 7).

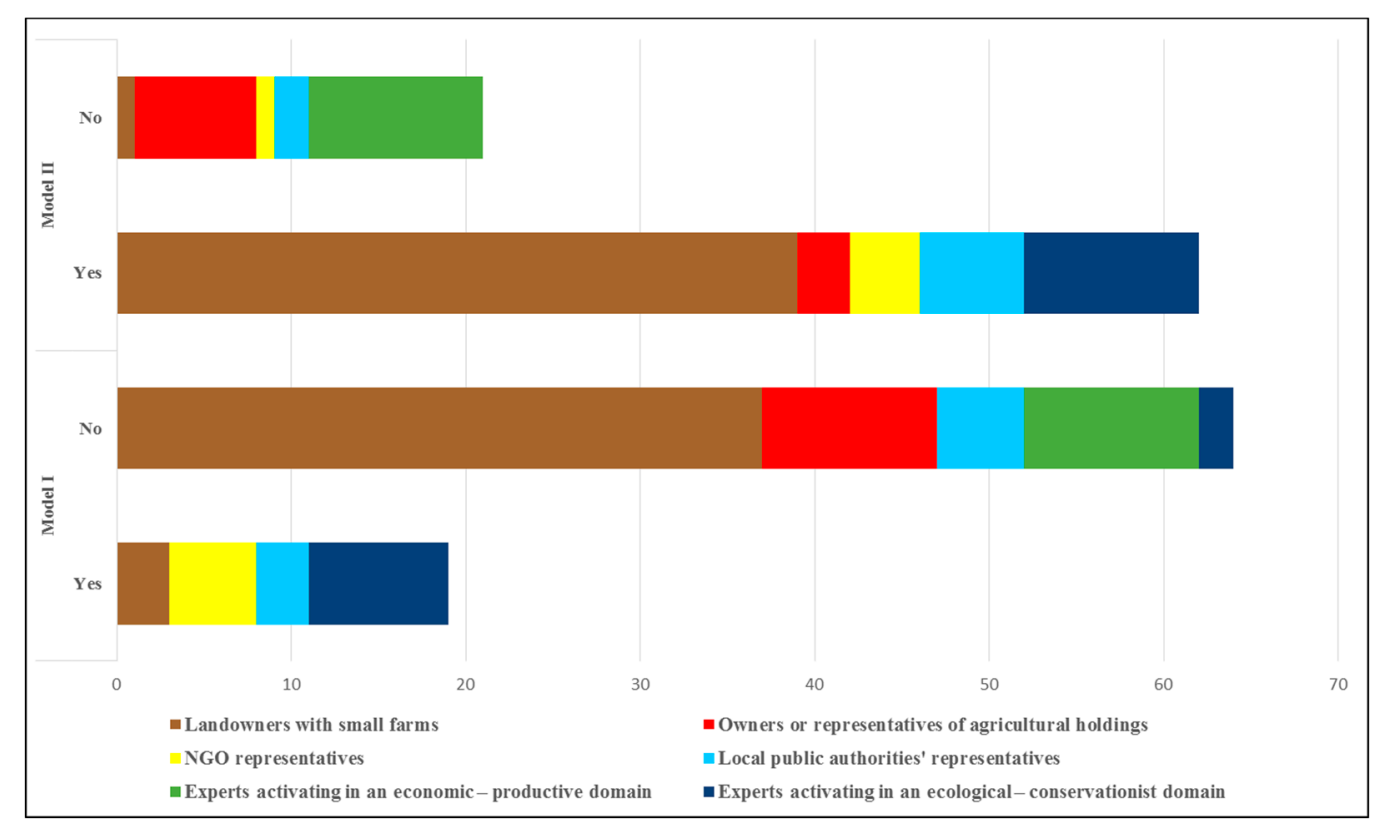

Figure 7. Stakeholders' degree of support for each of the two restoration models. Source: Data from the semi-structured interviews, 2019.

Furthermore, those that continue to work the land they own do that in order to receive special state subsidies (APIA-The Agency for Agricultural Payments and Interventions) which they consider as a great achievement.

"Conversely, if we would not receive the APIA subsidy, we would surely sell our arable lands because of high production costs; nothing would motivate us to keep them". (interview extract, landowner of a small farm, male, 62 years old, from Ciuperceni)

Consequently, only a small part (7.5\%) of the interviewed landowners of small farms would accept an initiative of complete restoration of the floodplain, but asked that they receive a similar plot of land somewhere else or matching financial compensation. After being presented with the other model, $97.5 \%$ of this target group supported a partial ecological restoration which may bring forward a diversification of the local economic activities (agriculture, fishing, forestry, leisure, ecotourism, etc.). If this model would ever come to fruition, the landowners of small farms hope the entire community would benefit: "the ponds must not be rented to a single holding because if they did we would again not benefit from the profits they bring" (interview extract, landowner of a small farm, male, 35 years old, Suhaia). 
The main conclusion from the discussions with the landowners of small farms was that they are poorly informed about the benefits that an ecological restoration would bring to the sector of the floodplain they live in as well as about the opportunities a territorial concept such as economic productivity through ecological protection would generate.

The representatives or owners of agricultural holdings conduct an intensive type of agriculture which they claim is highly performant and cannot justify giving it up, especially considering the substantial investments made when the infrastructure was built and the cost of its continued maintenance. As such, $100 \%$ of them declared that they were happy to keep the status quo. They did not complain about the manner in which they are currently managing and exploiting their lands with a few exceptions: The effects of some droughts, for example, in 2000, 2007, and 2015; the defective irrigation systems, etc. During the discussions, they thoroughly rejected a complete ecological restoration as it would work against their interests (see Figure 7). "We practice agriculture on vast areas in the Danube floodplain; our technologies are performant, as such a complete restoration would be an impediment for $u s^{\prime \prime}$ (interview extract, agronomist engineer, representative of an agricultural holding, 52 years old, Zimnicea).

When the possibility of a partial ecological restoration was presented, only $30 \%$ of them inclined towards a partial redevelopment. Those that agreed with this change did so on condition that financial compensation from the state to those landowners or land concessionaires that agree to a possible ecological restoration would be granted.

Local public authorities' representatives were satisfied in terms of $50 \%$ with the current status quo, at least for the time being, but concurred that central authorities should take additional steps to sustain members of the local community (e.g., simplifying the bureaucracy of the agricultural system, facilitating the access of small farmers or landowners with small farms to European funds). Their position varied depending on the type of restoration proposed. A total of $37.5 \%$ of them supported a model that included a complete ecological restoration, and $75 \%$ of them supported a model of a partial restoration but only if central authorities would create and implement a general restoration plan adapted to the specifications of each embankment located on the Romanian sector of the Danube floodplain. The local authorities' representatives declared being willing to consult with representatives from neighbouring counties in order to ensure that the final decisions would best help their communities.

"We agree with a partial ecological restoration, but it has to be integrated for everybody living in the Danube floodplain, we have to support the small farmers but also the agricultural holdings because the latter are the biggest source of taxes for the local budgets". (interview extract, local councillor, man, 58 years, Suhaia)

Another group with divided opinions was the one made up of experts, only this time the division was clear cut in the middle, with $50 \%$ of them supporting keeping the status quo while the other $50 \%$ of them voted for future actions that would envisage environmental conservation.

This split reflects the field of research of the interviewed experts. As such, experts in agricultural production and land use improvements, forestry, hydrology, or pedologists argued for the continuing practice of agriculture in the Danube floodplain due to several factors: The existing technical infrastructure, quality of the soils, their proximity to the river, etc. Moreover, they insisted that a restoration process, either complete or partial, would cause substantial damages to the agricultural infrastructure currently owned by the state or managed by the National Agency for Land Improvements, and affect other items (e.g., works for flood prevention, the arable lands themselves, households, production centres, zoo-technical complexes, and transport infrastructure located in the Danube floodplain). Therewith they argued for maintaining the status quo and further rehabilitating and modernising the existing land improvement structures (irrigation, draining), as well as consolidating Danube' banks and dikes; creating forest shelterbelts for land protection; waterproofing the water supply channels from the irrigation systems that remained unlined; foresting the areas between dikes 
and the riverbank, as well as low elevation areas that are presently not suitable for agriculture, etc. At the same time, they questioned the financial justifications of replacing agriculture with activities such as fishing, and hunting, reed processing, and establishing leisure structures.

"We want that agriculture remains the main activity in the Danube floodplain because we do not justify abandoning the infrastructure network built through enormous financial efforts by the state". (interview extract, agricultural expert, man, 56 years old)

Experts in environmental protection and conservation, geographers, biologists, part of the foresters, hydrologists, and pedologists all opposed keeping the status quo and any land-use model in which agricultural activities would prevail, but, rather, advocated for a complete (up to $80 \%$ of them) or partial ecological restoration through flooding individual sections $(100 \%)$. While expressing these opinions, all of them stressed that no matter what type of restoration is implemented, it is crucial that it will be done following the principles of sustainable development, which do not exclude agricultural production activities but require that they are balanced with the environmental requirements of the region. The arguments for partial ecological restoration numbered: Climate change (floods, frequent droughts, aridisation prone areas), increased biodiversity, diversification of the local economic activities (agriculture, fishing, forestry, tourism), etc.

"We would like to reconcile the economic role with the ecologic one in the Danube floodplain; we do not exclude production activities, but at the same time we support environmental protection and conservation". (interview extract, environmental conservation and protection expert, man, 43 years old)

The NGOs representatives supported both ecological restoration models but preferred the complete $(100 \%)$ to the partial one $(80 \%)$. They based their decisions on the European directives regarding flood prevention, the fact that these actions would increase biodiversity, and improve the quality of the environment overall, etc. The 2000 Declaration was signed by Romania, Bulgaria, the Republic of Moldova, and Ukraine that stipulates restoring wetlands along the lower Danube green corridor was, from their perspective, a steppingstone for achieving any type of ecological restoration.

\section{Discussion}

Buckley and Crone [56] concluded that restoration of ecological processes is inherently more controversial than conservation, especially in cases when the change involves converting land from one socially beneficial use, such as agriculture, to another.

The transformation of the wetlands into agro-systems during Romania's planned economy meant a reduction of their complex functions (e.g., ecologic, economic, social, and cultural) to a single one-economic. These results are similar to those obtained in studies from other floodplain systems from Europe and North America [57].

The two models proposed for the future land use in the study area are unique in the sense that, although the specialized national literature emphasised the need for ecological restoration, there is no detailed presentation of a possible model for this specific area of the Danube floodplain.

The balance between the economic aspect and the ecological benefits were the main engines in the design of the two models, and it would be achieved through specific and punctual modifications of some of the currently agricultural lands that have formerly been ponds, swamps, or flooded areas. For example, the first model proposed, while militating for a complete ecological restoration, takes into consideration the existing human structures (settlements, agricultural, industrial or transport infrastructure) and incorporates them. In the case of the second model, the authors proposed that the current arable surface in the study area is kept at approximately the same level but introduced forest shelterbelts on the arable lands. These would have an important ecological protection role. Moreover, this model contains room for the river, which are original distinctive elements for a land planning project in Romania. They will be placed on the former location of the Roșia and Călina 
lakes and will be surrounded by and irrigate green areas (an essential source of vegetables for the local population). Another method of balancing economic production with ecologic protection is the reintroduction of rice paddies around Suhaia Lake, as they will help moderate the climatic aridity of the study area. In keeping with the idea of obtaining a balance between humans and nature, the second model for ecological restoration does not exclude the agricultural component; on the contrary, it supports the diversification of the local economy.

Most importantly both models include changes in the land-use typology that would directly mitigate the effects of climate change: The newly formed wetlands would moderate air temperatures and humidity levels, while also serving as flooded areas in case of strong floods; the forest shelterbelt would protect agricultural lands from aridisation and soil erosion; rice paddies would moderate the local climate, which has aridity influences, by maintaining areas flooded several months per year during the summer season; and the room for the river would offer protection against flooding, while also irrigating the green areas set up around them.

A stakeholder analysis [58] was performed in order to define the position of each group in terms of interest and power for a possible ecological restoration of the Danube floodplain, as illustrated below in a stakeholder map (see Figure 8).

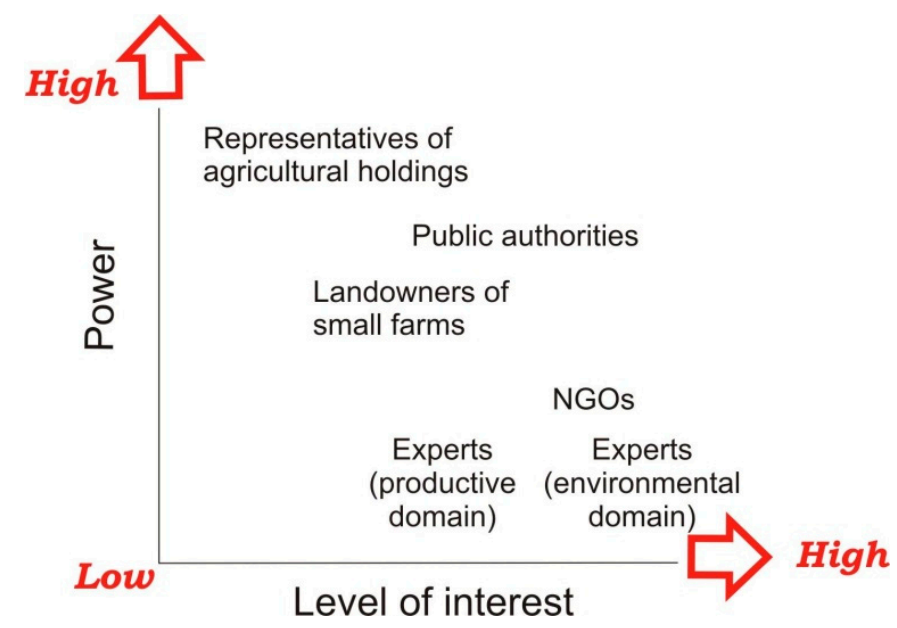

Figure 8. Mapping the power and interest level of stakeholders involved in the possible restoration of the Danube floodplain.

The main key actors or groups representing "dynamic" or "static" stakeholders [59] groups of people and/or individuals directly interested and/or affected by the ecological restoration of the area were:

- The farmers, further split into two distinctive groups: Landowners of small farms, more numerous but less important as economic and decisional power; and owners or representatives of agricultural holdings. The latter group is by far the most influential on the final usage of the land they own or lease, being the most affected by the land use and environmental changes in the region. Dynamic and highly interested in the economic effects of the ecological restoration, this group is the most influential in relation to the other groups in their attempt to determine the orientation of the development policies in the area.

- The public authorities at the local level represent another key stakeholder we approached. In charge of formulating policy agendas and objectives, spreading public information, but also with addressing and mediating conflicts, they are supposed to "support a decision-making process that is based on the value of consensus", even if in practice the political affiliations and economic considerations influence the decision-making process [60]. Consequently, they are a group displaying both a considerable power and interest in the ecological restoration of the Danube floodplain. 
- The NGO's represent an important voice sometimes influencing the political factor in the design of environmental policies and displaying a high interest in the ecological restoration

- Two distinctive groups of experts interested to different extents in a full or partial ecological restoration of the studied area, as they represent ecologists (experts in the environmental domain) or economists (experts in the productive domain, mainly agronomist engineers), are key stakeholder groups placed at the bottom of the power scale. They display a high and a very high interest but a low operational capacity (power) to influence and determine the change of the current land use in the area.

The findings from the discussions with the stakeholders revealed that their opinions varied, with every group presenting arguments for or against each of the proposed models of ecological restoration. The key positions the stakeholders adopted referred to: Maintaining the status quo, supporting the first ecological restoration model more, and supporting the second restoration model more.

The most important conflict for implementing any ecological restoration project in the study area stems from the fact that all groups, except the experts in the environmental domain and the NGOs' representatives, prefer to maintain the status quo. Their reasoning is most of the time financial: Ecological restoration equals an immediate decrease in agricultural production and hence economic profits. Other reasons for this position stems from misinformation or mistrust in the political or administrative system.

NGOs representatives and the experts in the environmental domain strongly sustained the idea of a complete ecological restoration and brought forward arguments such as the European directive for adapting to climate change, and the fact that the second model would increase biodiversity and improve the environment.

Most of the stakeholders (landowners of small farms, owners or representatives of agricultural holdings, local public authorities' representatives, public authorities' representatives, experts in the productive domain) supported to a stronger degree the second restoration model. They declared that while they acknowledge something has to be done to mitigate the damages of climate change, a major barrier is the fact that an ecological restoration will bring with it a decrease in their agriculture revenues, and the rest of the economic activities that could develop in the area will need time to become profitable.

A large spectrum of opinions about an ecologic restoration of floodplains is not unique. Studies from the USA presented social unrest caused by such processes, with one of the most common conclusions being that people are, in general, reluctant to change [13]. While this mirrors the finding of our study, it is important going forward that the cause of this scepticism is clearly understood. In the case of our study area, it stems from the local population' conservative attitude generated by the change in paradigm regarding their own ownership status over the land. It can be explained by them experiencing two types of government: Both a system of centralised economy and a free market economy, each with their pros and cons.

\section{Conclusions}

The study is innovative because it constructs two possible ecological restoration models in an area of the Danube floodplain that has not been analysed before at this detailed level. Apart from that, the study also contains the needs assessments of the stakeholders directly involved in the current and future use of the plots from the Danube floodplain as well as balancing their opinion with input from specialised expert opinions. This brought forward the most important conflict: The fact that any future implementation of either the proposed model or any other ecological restoration effort would first have to deal with a conservative opinion of the involved stakeholders, which would always prefer to maintain the status quo either because of the financial security current land-use typology ensures or because of the inherent fear of the unknown. 
The conclusion of this research is that the present preoccupation with ecological restoration of the Danube floodplain should continue as the study area has a long history of human transformations of the environment and the multiple artificial conversions in land use, as well as the powerful soil erosion, are no longer viable in the current conditions brought by climate change trends. A possible ecological restoration needs to ensure tangible alternatives to the continuity of agricultural production, animal farming, and forestry that the local communities are presently practising, while also providing a sustainable balance between the environment and economic activities. The most important element is constructing a participative, balanced, and smart strategy which would mediate the interests of each stakeholder group without jeopardising the common concern of local communities-their quality of life.

Author Contributions: The authors contributed equally to this work (I.V.-literature review, writing, data analysis and interpretation for the first objective, preparation of final draft; G.M. and M.P.-literature review, writing, data analysis and interpretation for the second objective; social perception; A.I.L.-D.--literature review, methodology, text improvement, preparation of the final draft; E.M.--literature review, methodology; R.C.—collected and computed data using GIS technologies; A.T. and A.M.--literature review, applied interviews, contributed to the analysis and text improvement, preparation of the final draft).

Funding: The publication of this research has been partially funded by the Faculty of Geography, University of Bucharest, Romania.

Acknowledgments: We thank Mr. Cristian Ioan Iojă (Department of Regional Geography and Environment, University of Bucharest, Romania) for his valuable comments, suggestions, and support, and also to Morgaine Green for her invaluable help in proofreading this material. The authors would also like to thank the editors and anonymous reviewers for their constructive comments and helpful suggestions.

Conflicts of Interest: The authors declare no conflicts of interest with respect to the research, authorship, and/or publication of this article.

\section{References}

1. Solomon, S.; Qin, D.; Manning, M.; Averyt, K.; Marquis, M.; Tignor, M.M. Climate Change 2007-The Physical Science Basis: Working Group I Contribution to the Fourth Assessment Report of the IPCC; Cambridge University Press: Cambridge, UK, 2007; Volume 4.

2. Guo, B.; Xie, T.; Subrahmanyam, M. The Impact of China's Grain for Green Program on Rural Economy and Precipitation: A Case Study of Yan River Basin in the Loess Plateau. Sustainability 2019, 11, 5336. [CrossRef]

3. Hilderbrand, R.H.; Watts, A.C.; Randle, A.M. The myths of restoration ecology. Ecol. Soc. 2005, 10, 19. [CrossRef]

4. Egan, D.; Hjerpe, E.E.; Abrams, J.; Higgs, E. Human Dimensions of Ecological Restoration: Integrating Science, Nature, and Culture; Island Press: Washington, DC, USA, 2012.

5. Hulea, O.; Ebert, S.; Strobel, D. Floodplain restoration along the Lower Danube: A climate change adaptation case study. IOP Conf. Ser. Earth Environ. Sci. 2009, 6, 402002. [CrossRef]

6. Munich, R. Annual Review: Natural Catastrophes 2004; Knowledge Series; Münchener Rück: München, Germany, 2005.

7. Dankers, R.; Christensen, O.B.; Feyen, L.; Kalas, M.; de Roo, A. Evaluation of very high-resolution climate model data for simulating flood hazards in the Upper Danube Basin. J. Hydrol. 2007, 347, 319-331. [CrossRef]

8. Kundzewicz, Z.W.; Ulbrich, U.; Graczyk, D.; Krüger, A.; Leckebusch, G.C.; Menzel, L.; Pińskwar, I.; Radziejewski, M.; Szwed, M. Summer floods in Central Europe-climate change track? Nat. Hazards 2005, 36, 165-189. [CrossRef]

9. Galat, D.L.; Fredrickson, L.H.; Humburg, D.D.; Bataille, K.J.; Bodie, J.R.; Dohrenwend, J.; Gelwicks, G.T.; Havel, J.E.; Helmers, D.L.; Hooker, J.B.; et al. Flooding to Restore Connectivity of Regulated, Large-River Wetlands: Natural and controlled flooding as complementary processes along the lower Missouri River. BioScience 1998, 48, 721-733. [CrossRef]

10. Sparks, R.; Braden, J.; Demissie, M.; Mitra, P.; Schneider, D.; White, D.; Xia, R. Technical Support of Public Decisions to Restore Floodplain Ecosystems: A Status Report on the Illinois River Project, USA; Backhuys Publishers: Leiden, The Netherlands, 2000; pp. 225-247. 
11. Ahn, C.; Johnston, D.M.; Sparks, R.E.; White, D.C. Analysis of naturalization alternatives for the recovery of moist-soil plants in the floodplain of the Illinois River. In Living Rivers: Trends and Challenges in Science and Management; Leuven, R.S.E.W., Ragas, A.M.J., Smits, A.J.M., van der Velde, G., Eds.; Springer: Dordrecht, The Netherlands, 2006; pp. 217-228.

12. Sparks, R.E. Need for Ecosystem Management of Large Rivers and Their Floodplains. BioScience 1995, 45, 168-182. [CrossRef]

13. Sparks, R.E.; Braden, J.B. Naturalization of Developed Floodplains: An Integrated Analysis. J. Contemp. Water Res. Educ. 2007, 136, 7-16. [CrossRef]

14. Sparks, R.E.; Nelson, J.C.; Yin, Y. Naturalization of the Flood Regime in Regulated Rivers: The case of the upper Mississippi River. BioScience 1998, 48, 706-720. [CrossRef]

15. Declaration on the Cooperation for the Creation of a Lower Danube Green Corridor. 2000. Available online: http://awsassets.panda.org/downloads/ldgcdeclaration.pdf (accessed on 5 May 2019).

16. Danube Delta National Institute for Research and Development. The Ecological and Economic Resizing Programme in Romanian Sector of the Danube Floodplain; Contract No. 3683/M.M.D.D./2006; Danube Delta National Institute for Research and Development: Bucharest, Romania, 2008.

17. Nichersu, I. Flood risk management, ecological and economical resizing in Danube Floodplain and Danube Delta spatial planning. In Proceedings of the Danube Environment Forum, Tulcea, Romania, 27-29 June 2013.

18. Stoiculescu, C.D. Reconstrucţia Ecologică a Zonei Inundabile a Dunării Româneşti; SC Green Steps SRL: Bucharest, Romania, 2008.

19. Monitorul Oficial al României. Government Decision No. 2151/30.11.2004 on the Establishment of Protected Natural Area Regime for New Regions; Monitorul Oficial al României: Bucharest, Romania, 2005.

20. Monitorul Oficial al României. Government Decision No. 1284/24.10.2007 on Establishing Special Avifaunistic Protection Areas as Integral Part of the European Ecological Network Natura 2000; Monitorul Oficial al României: Bucharest, Romania, 2007.

21. Ramsar Convention. Romania. 2019. Available online: https://www.ramsar.org/countries/romania?page=3 (accessed on 10 June 2019).

22. Danube Floodrisk Final Report. 2012. Available online: http://www.oerok-projektdatenbank.at/upload/206_ Danube\%20Floodrisk\%20Final\%20Report.pdf (accessed on 29 September 2019).

23. Rădulescu, D.; Chendeș, V.; Ion, M.B. Realizarea hărţilor de hazard şi risc pe teritoriul României, conform cerinţelor Directivei 2007/60/CE. Rev. Asoc. Române Ştiinţe Hidrol. 2014, 9, 19-23.

24. Posner, C. Analiza Strategiilor de Adaptare la Inundații ale Comunităților Locale Prin Folosirea Metodelor Tradiționale și Participative de Cercetare. Studiu de Caz: Valea Dunării Între Giurgiu și Gostinu. Ph.D. Thesis, University of Bucharest, București, Romanian, 2015.

25. Hein, T.; Schwarz, U.; Habersack, H.; Nichersu, I.; Preiner, S.; Willby, N.; Weigelhofer, G. Current status and restoration options for floodplains along the Danube River. Sci. Total Environ. 2016, 543, 778-790. [CrossRef] [PubMed]

26. Funk, A.; Martínez-López, J.; Borgwardt, F.; Trauner, D.; Bagstad, K.J.; Balbi, S.; Magrach, A.; Villa, F.; Hein, T. Identification of conservation and restoration priority areas in the Danube River based on the multi-functionality of river-floodplain systems. Sci. Total Environ. 2019, 654, 763-777. [CrossRef] [PubMed]

27. The National Strategy for Sustainable Development-Romania 2030. Available online: https://www. edu.ro/sites/default/files/Strategia-nationala-pentru-dezvoltarea-durabila-a-Rom\%C3\%A2niei-2030.pdf (accessed on 16 June 2019).

28. European Parliament; Council of Europe. Directive 2000/60/EC of the European Parliament and of the Council Establishing a Framework for Community Action in the Field of Water Policy; European Parliament: Belgium, Brussels; Council of Europe: Strasbourg, France, 2000.

29. European Parliament; Council of Europe. Directive 2007/60/EC of the European Parliament and of the Council of 23 October 2007 on the Assessment and Management of Flood Risks; European Parliament: Belgium, Brussels; Council of Europe: Strasbourg, France, 2007.

30. Gren, M.; Groth, K.-H.; Sylvén, M. Economic values of Danube floodplains. J. Environ. Manag. 1995, 45, 333-345. [CrossRef] 
31. Dorondel, Ș.; Armaș, I.; Florian, V.; Rusu, M.; Posner, C.; Șerban, S. Ghid de Bune Practici Privind Transformările Socio-Economice și de Mediu Din Lunca Dunării; Francisc I. Rainer Institute of Anthropology: București, Romania, 2016. Available online: https://www.researchgate.net/publication/308746883_GHID_DE_BUNE_PRACTICI_ PRIVIND_TRANSFORMARILE_SOCIO-ECONOMICE_SI_DE_MEDIU_DIN_LUNCA_DUNARII (accessed on 7 November 2019).

32. Ivan, O. Trăind cu apele. Cum se adaptează o comunitate la încă o reconfigurare a peisajului din Lunca Dunării. Natl. Geogr. 2015, 12, 104-113.

33. Buijs, A.E. Public support for river restoration. A mixed-method study into local residents' support for and framing of river management and ecological restoration in the Dutch floodplains. J. Environ. Manag. 2009, 90, 2680-2689. [CrossRef]

34. Neuman, W.L.; Robson, K. Basics of Social Research: Qualitative and Quantitative Approaches; Pearson: Boston, MA, USA, 2007; p. 48.

35. Berg, B.L. Qualitative Research Methods for the Social Sciences, 7th ed.; Allyn\&Bacon: Boston, MA, USA, 2009.

36. Crossman, A. Conducting Case Study Research in Sociology 2019. Available online: https://www.thoughtco. com/case-study-definition-3026125 (accessed on 10 July 2019).

37. Syme, W.; Pinnell, M.; Wicks, J. Modelling flood inundation of urban areas in the UK using 2D/1D hydraulic models. In Proceedings of the 8th National Conference on Hydraulics in Water Engineering, Paradise, QLD, Australia, 13-16 July 2004; The Institution of Engineers: Barton, ACT, Australia, 2004.

38. Rood, S.B.; Samuelson, G.M.; Braatne, J.H.; Gourley, C.R.; Hughes, F.M.; Mahoney, J.M. Managing river flows to restore floodplain forests. Front. Ecol. Environ. 2005, 3, 193-201. [CrossRef]

39. Lamouroux, N.; Gore, J.A.; Lepori, F.; Statzner, B. The ecological restoration of large rivers needs science-based, predictive tools meeting public expectations: An overview of the Rhône project. Freshw. Biol. 2015, 60, 1069-1084. [CrossRef]

40. Lin, B.; Wicks, J.M.; Falconer, R.A.; Adams, K. Integrating 1D and 2D hydrodynamic models for flood simulation. In Proceedings the Institution of Civil Engineers-Water Management; ICE Virtual Library: London, UK, 2006; pp. 19-25.

41. Wallingford, H. ISIS Flow User Manual; HR Wallingford: Wallingford, UK, 1997.

42. Crooks, S.; Naden, P. CLASSIC: A semi-distributed rainfall-runoff modelling system. Hydrol. Earth Syst. Sci. Discuss. 2007, 11, 516-531. [CrossRef]

43. Bradbrook, K. JFLOW: A multiscale two-dimensional dynamic flood model. Water Environ. J. 2006, 20, 79-86. [CrossRef]

44. European Environment Agency. Corine Land Cover Accounting Layers. Available online: https://www.eea. europa.eu/data-and-maps/data/corine-land-cover-accounting-layers (accessed on 29 June 2019).

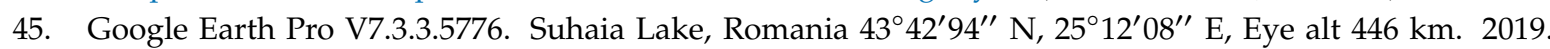
Available online: https://www.google.com/intl/ro/earth/ (accessed on 1 July 2019).

46. The Geo-Spatial Cartographic Database. Available online: http://geo-spatial.org/ (accessed on 20 June 2019).

47. Lozato-Giotart, J.-P. Géographie du Tourisme: De L'espace Consommé à L'espace Maîtrisé; Pearson Education: Montreuil, France, 2003.

48. Popovici, E.; Bălteanu, D.; Kucsicsa, G. Utilizarea terenurilor și dezvoltarea actuală a agriculturii. In România. Natură şi Societate; Editura Academiei Române: Bucharest, Romania, 2016; pp. 329-374.

49. Tudor, C.A.; Iojă, I.C.; Rozylowicz, L.; Pătru-Stupariu, I.; Hersperger, A.M. Similarities and differences in the assessment of land-use associations by local people and experts. Land Use Policy 2015, 49, 341-351. [CrossRef]

50. Stylidis, D.; Biran, A.; Sit, J.; Szivas, E.M. Residents' support for tourism development: The role of residents' place image and perceived tourism impacts. Tour. Manag. 2014, 45, 260-274. [CrossRef]

51. Vinke-de Kruijf, J. The Role of Dutch Expertise in Romanian Water Projects: Case Study "Room for the River in Cat's Bend, Romania"; University of Twente: Enchede, The Netherlands, 2011.

52. Warner, J.F.; van Buuren, A.; Edelenbos, J. Making Space for the River; IWA Publishing: London, UK, 2012.

53. Antipa, G. Regiunea Inundabilă a Dunării. Starea ei Actuală și Mijloacele de a o Pune în Valoare; Institutul de Arte Grafice Carol Gobl: Bucharest, Romania, 1910.

54. Vijulie, I.; Manea, G.; Tîrlă, L.; Matei, E.; Preda, M.; Cuculici, R. Revival of the Rice Crops in the South of Romania: Pros and Cons. Procedia Environ. Sci. 2016, 32, 373-385. [CrossRef]

55. Monitorul Oficial al României. Land Fund Law No.18; no 37/20.02.1991; Monitorul Oficial al României: Bucharest, Romania, 1991. 
56. Buckley, M.C.; Crone, E.E. Negative Off-Site Impacts of Ecological Restoration: Understanding and Addressing the Conflict. Conserv. Biol. 2008, 22, 1118-1124. [CrossRef] [PubMed]

57. Tockner, K.; Stanford, J.A. Riverine flood plains: Present state and future trends. Environ. Conserv. 2002, 29, 308-330. [CrossRef]

58. Grimble, R.; Wellard, K. Stakeholder methodologies in natural resource management: A review of principles, contexts, experiences and opportunities. Agric. Syst. 1997, 55, 173-193. [CrossRef]

59. Mendelow, A.L. Environmental Scanning-The Impact of the Stakeholder Concept. In Proceedings of the International Conference on Information Systems - ICIS, Cambridge, MA, USA, 7 December 1981; p. 20. Available online: https://aisel.aisnet.org/icis1981/20 (accessed on 7 November 2019).

60. McGinnis, M.V.; Woolley, J.; Gamman, J. Bioregional conflict resolution: Rebuilding community in watershed planning and organizing. Environ. Manag. 1999, 24, 1-12. [CrossRef] [PubMed]

(C) 2019 by the authors. Licensee MDPI, Basel, Switzerland. This article is an open access article distributed under the terms and conditions of the Creative Commons Attribution (CC BY) license (http://creativecommons.org/licenses/by/4.0/). 